DOI: 10.2478/atd-2019-0015

\title{
Determination of the Empathy Levels of Prospective Classroom Teachers: An Example of the Life Skills Teaching Course
}

\author{
Nur Ütk ür* \\ Received: September 4, 2019; received in revised form: October 4, 2019; \\ accepted: October 7, 2019
}

\begin{abstract}
:
Introduction: The concept of empathy has been described in many ways by researchers. According to some, it is the basic cognitive function or ability of being aware of others' thoughts and feelings. Empathy refers to being able to respond to emotions, sharing the feelings of individuals, and reflecting them as if in a mirror. It also helps to establish good relationships with people, to understand them, and share their feelings. The use of empathy in the classroom, especially in life skills courses help students to make connections between school and everyday life.

Methods: This study aimed to investigate how an empathy-based education programme implemented in the life skills teaching course affected the empathy skills of prospective classroom teachers in Turkey. For this purpose, using a mixed-methods research design, the participant prospective classroom teachers received empathy-based education programme 12 class hours. The data collection tools used in the study were the Empathy Quotient Scale, document analysis and open-ended questionnaire. The study was conducted with 64 prospective classroom teachers attending at Istanbul University, Turkey. The dependent t-test was employed to analyze the quantitative data and content analysis for qualitative data.

Results: As a result, it was seen that the qualitative data supported the quantitative data. According to the quantitative data, after receiving empathy-based education programme, the students developed the skills of empathy. According to the qualitative data, it was determined that prospective teachers understood the importance of empathy and put themselves in the place of others. In addition, the prospective teachers considered that empathy would have several positive contributions to their future primary school students. It is thought that the results obtained from this study will guide teaching practices involving empathy-based activities.
\end{abstract}

\footnotetext{
* Nur Ütkür, Istanbul University-Cerrahpasa, Hasan Ali Yucel Education Faculty, Istanbul, Turkey; nur.utkur@istanbul.edu.tr
} 


\section{Acta Educationis Generalis \\ Volume 9, 2019, Issue 3}

Discussion: According to the findings obtained from the quantitative data, the empathy-based education programme provided for the prospective teachers caused a significant increase in their empathy levels. Similarly, in a study who applied a critical thinking programme and empathic tendency scale to prospective teachers, reported a positive correlation between critical thinking and empathic tendency at a low-level significance. According to the findings obtained from the qualitative data, the topics chosen for the preparation of empathy-based activities were mostly from the life skills subjects of the first grade of primary school, followed by second and third grades. This may be because the prospective teachers considered it appropriate to perform empathy-based activities with children from the earliest age. Furthermore, a higher number of participants chose to prepare written empathy-based activities, followed by drawing and photography, which might be attributed to their belief that they could better express themselves through writing, rather than drawing or taking/showing pictures.

Limitations: The study group covered in the third year of the classroom teaching programme in the selected university only. Although the empathy-based education programme prepared by the researcher was implemented with the prospective teachers as part of the life skills teaching course in 10 class hours.

Conclusions: In conclusion, empathy is considered to be very important especially in the education of children of young age. As revealed by the review of literature, empathy skills also affect many positive elements. For this reason and considering that the available research in the literature is based either on quantitative or on qualitative data, more mixed-design studies are needed to investigate the effects of similar empathy-based education programmes integrated into life skills and social studies courses. In addition, it is as important to conduct empathy-based activities in other courses of the primary and middle school as in life skills and social studies courses. It is also suggested that empathy-based education should also be provided for teacher candidates enrolled in science teaching programmes, as well as those in social studies.

Key words: empathy; empathy-based education programme; life skills course; primary education; Turkey.

\section{Introduction}

Empathy is considered as being important in relationships with others. One of the most important ways to understand and communicate well with other people is to empathise with them. LeCompte (2000) suggested that empathy was a crucial component for healthy relationships. Empathy is also a necessary characteristic and skill to establish a partnership between teachers and the families of the children attending the school. Healthy relationships between teachers and parents are essential for family-school partnerships (as cited in Peck, Maude, \& Brotherson, 2015). 


\section{Acta Educationis Generalis \\ Volume 9, 2019, Issue 3}

The concept of empathy has been described in many ways by researchers. According to some, it is the basic cognitive function or ability of being aware of others' thoughts and feelings (Bartnett, 1990; Borke, 1971, as cited in Şahin, 2012). Empathy refers to being able to respond to emotions, sharing the feelings of individuals, and reflecting them as if in a mirror. It also helps to establish good relationships with people, to understand them, and share their feelings (Krznaric, 2008).

For teachers, an important point in the process of empathy is that they have sufficient knowledge and can shape their lessons accordingly. Carkhuff and Berenson (1967) conducted a study on this subject, proposing a teacher empathy model that included the ability to understand and describe the feelings and perspectives of an individual and convey this understanding to that person (as cited in Feshbach \& Feshbach, 2009). Teacher empathy is very important for students in various classroom situations. In addition, as stated by Tettegah (2007), teachers' use of empathy in the classroom affects the teacher-student relationship and the level of students' self-confidence. Many problems experienced in the classroom are known to be due to lack of empathy.

The use of empathy in the classroom, especially in life skills courses help students to make connections between school and everyday life. In Turkey, the life skills course is taught in the first three years of primary school, followed by the social studies course in the fourth grade. Life skills and social studies are not only subsequent but also complementary courses. Both are characterized by a variety of elements from children's daily lives. In addition, with their components related to the communication and empathy skills included in the 2018 curriculum, these courses are considered to be highly appropriate to help students gain empathy (Ministry of National Education, 2018). The classroom teaching programmes of education faculties for prospective teachers contain life skills which include empathy.

The literature contains various studies on empathy in education (Barnett \& Thompson, 2001; Ekinci \& Aybek, 2010; Elikesik \& Alım, 2013; Feshbach \& Feshbach, 2009; Kabapınar, 2004; Kabapınar, 2005; Krznaric, 2008; Mareš, 2017; McAllister \& Irvine, 2002; Peck, Maude, \& Brotherson, 2015; Sinclair \& Fraser, 2002; Şahin, 2012; Tamášová \& Barnová, 2019; Tettegah, 2007; Uzunkol \& Yel, 2016); however, to the best of the author's knowledge, there is no study based on the mixed method design to measure the effects of empathybased education for prospective teachers on their empathy levels. Therefore, this study is considered to offer a significant contribution to the literature.

The main purpose of this study was to determine the effect of empathy-based education on the empathy of prospective teachers. For this purpose, answers to the following research questions were sought:

1. Is empathy-based education provided for prospective teachers effective in increasing their empathy levels? 


\section{Acta Educationis Generalis \\ Volume 9, 2019, Issue 3}

2. What type of topics and empathic roles do prospective teachers choose to prepare empathy-based activities?

3. What are the types of empathy chosen by prospective teachers in the preparation of empathy-based activities?

4. How do prospective teachers feel when preparing empathy-based activities?

5. What are the views of prospective teachers concerning the benefits of empathy-based activities for their future primary school students?

\section{Methods}

\subsection{Research design}

In this study, a mixed research design including both quantitative and qualitative methods was used. Quantitative methods were used to determine the effect of empathy-based education on the empathy levels of prospective teachers. In the quantitative part of the study, a single-group pre-test and post-test design was employed. In this method, first a pre-test is administered to the group, then the teaching programme is implemented, and finally the post-test is applied (Creswell, 2016). In the qualitative part of the research, qualitative methods were utilized to determine the activities prepared by prospective teachers within their education programme, their views, and the characteristics of the outputs.

\subsection{Research sample}

The study was conducted at Istanbul University, Turkey in the 2017-2018 academic year. For the selection of the study group, ease of accessibility to the sample was taken into consideration (Patton, 2014). The study group consisted of 64 prospective teachers, 35 females and 29 males, enrolled in the third year of the classroom teaching programme in the selected university. In this study, the reason for selecting prospective teachers from the third year was that in Turkey, the life sciences teaching course is offered in this year as part of the classroom teaching programs in education faculties. In addition, the prospective teachers being willing to volunteer to participate in this research were taken into account during the sample selection.

\subsection{Data collection tools}

The data collection tools were the Empathy Quotient scale for the quantitative part of the research and an open-ended questionnaire for the qualitative part.

\section{The Empathy Quotient}

This scale was developed by Lawrence et al. (2004) and adapted by Kaya and Çolakoğlu (2015) for prospective teachers enrolled in social studies teaching programmes. The original version of the scale consists of 60 items including 20 distractors under three factors. The exploratory factor analysis conducted for construct validity showed that the adapted version consisted of 13 items. 


\section{Acta Educationis Generalis \\ Volume 9, 2019, Issue 3}

Consistent with the original scale, the adapted version consists of three subscales: social skills, emotional response, and cognitive empathy. The reliability of the adapted scale was calculated according to different samples in two stages. The reliability coefficients for the whole scale and the three subscales were determined as $.78, .64, .71$ and .74 , respectively in the first stage, and $.86, .61, .75$ and .74 , respectively in the second stage.

\section{Open-ended questionnaire}

An open-ended questionnaire was administered to the participants to determine their views on the empathy-based education programme. The data were transcribed and analysed using codes and categories appropriate for the purpose. The items in the questionnaire aimed to reflect the feelings and thoughts of the prospective teachers during the implementation of empathybased activities and the potential benefits of these activities for the future primary school students they would teach.

While determining the criteria to be considered in document analysis and openended questionnaire items, opinions of expert instructors and classroom teachers were sought to ensure validity, and in accordance with their feedback, the final versions of the criteria and items were obtained. The opinions of a total of eight experts (four instructors working at Marmara University and four classroom teacher teachers working at a public primary school) were subjected to the Lawshe content validity test (as cited in Yurdugül, 2005). The content validity indexes of the items were calculated and confirmed to serve the purpose of the measurement. The content validity index was determined as 0.99 for the document analysis criteria and 0.94 for the open-ended questionnaire, indicating the validity of both measures.

\subsection{Procedure}

In the research process, before applying the empathy-based education programme, the Empathy Quotient scale was administered to the participants as a pre-test. Then, the empathy-based education programme prepared by the researcher was implemented with the prospective teachers as part of the life skills teaching course in 10 class hours.

In every step of the preparation of this programme, opinions were received from the faculty members and teachers. According to expert opinions, various modifications were made to the content of the education programme and the questions to be directed to the students. In this process, a total of eight experts were consulted, and the Lawshe content validity test was applied (as cited in Yurdugül, 2005). The stages and activities included in the programme were considered as an item, and the content validity index was calculated. The content validity index was determined as 0.95 . Thus, the education programme was found to be valid for teaching empathy and reflecting its use in the classroom environment. 


\section{Acta Educationis Generalis \\ Volume 9, 2019, Issue 3}

The stages and characteristics of the implemented education programme are summarised below.

1) Preparation and awareness-building

- Brainstorming what empathy is,

- Showing examples of drawings and cartoons supporting empathy,

- Emphasising the importance of empathy, supported by the literature,

- Focusing on the importance of empathy for the life skills course,

- Discussing the types of empathy.

\section{2) Development and implementation}

- Discussing empathic roles with examples,

- Describing the basic criteria associated with empathy,

- Describing quality improvement criteria associated with empathy,

- Providing examples of empathy through writing, photography and drawing,

- Empathy-based activities using empathic roles.

3) Obtaining and evaluating the results

- Presentation/reading of empathy-based outputs,

- Peer assessment,

- Comparison of the outputs with previous empathy-based work,

- Discussing the empathic characteristics of other teaching methods, such as case study, drama, and the six thinking hats system,

- Discussing the importance of empathising in the classroom as a teacher.

After implementing the empathy-based education programme, the Empathy Quotient scale was administered to the prospective teachers again as a post-test. Then, the open-ended questionnaire was applied to elicit the views of the prospective teachers about the programme and activity preparation process. Furthermore, the document analysis of the outputs presented by the participants was undertaken by the researcher.

\subsection{Data analysis}

In the analysis of the quantitative data; i.e., the pre-test and post-test results, a related-samples t-test was performed using SPSS software. The significance of the obtained results was examined.

In the qualitative part of the research, the data obtained from document analysis and open-ended questionnaires were analysed using the content analysis method. These data were coded in relation to the characteristics of empathy. The common aspects of these codes were determined to identify subthemes. All data were classified under these themes. In addition, in order to support these themes, 


\section{Acta Educationis Generalis \\ Volume 9, 2019, Issue 3}

quotations and examples from the views of prospective teachers were included using pseudonyms; e.g., S1, S2, S3, etc.

In the analysis of the qualitative data, to ensure coder reliability, an expert instructor provided support and was asked to re-encode the data obtained during the content analysis of the open-ended questionnaire and interview forms. The coding of the researcher and the other instructor was compared, and the intercoder reliability was calculated using the formula of Miles and Huberman (1994): Reliability $=$ Number of Agreements/Number of Disagreements + Number of Agreements. According to Miles and Huberman (1994), when this value is greater than 0.80 , the analysis is considered reliable. The mean coefficient of the researcher and expert analyses was determined as 0.96 for the document analysis and 0.90 for the results of the open-ended questionnaire. Accordingly, being above 0.80 , all analyses undertaken with the data collection tools in this study were considered to be reliable.

\section{Results}

2.1 Effect of the empathy-based education programme on the empathy levels of prospective teachers

Table 1 presents the results of the related samples t-test performed on the data obtained from the Empathy Quotient scale administered to the prospective teachers before and after the implementation.

Table 1

The results of the related samples t-test on the Empathy Quotient pre-test and post-test scores of the participants

\begin{tabular}{|c|c|c|c|c|c|c|}
\hline \multirow{2}{*}{ Empathy Quotient scale } & \multirow{2}{*}{$N$} & \multirow{2}{*}{$X$} & \multirow{2}{*}{$S d$} & \multirow{2}{*}{$S H_{x}$} & \multicolumn{2}{|c|}{ t test } \\
\hline & & & & & $t$ & Sig. \\
\hline Pre-test & 64 & 3.99 & .37 & .04 & \multirow{2}{*}{-3.809} & \multirow{2}{*}{.000} \\
\hline Post-test & 64 & 4.20 & .19 & .02 & & \\
\hline
\end{tabular}

These results revealed a statistically significant difference between the pre-test and post-test scores of the prospective teachers $(t=-3.809, \mathrm{p}<.01)$. The posttest scores of the prospective teachers (4.20) were significantly higher than their pre-test scores (3.99). This means that the empathy-based education programme resulted in a significant increase in the empathy levels of the prospective teachers. 


\section{Acta Educationis Generalis \\ Volume 9, 2019, Issue 3}

2.2 Topics and empathic roles chosen by prospective teachers in preparation of empathy-based activities

The empathic roles chosen by prospective teachers for the preparation of empathy-based activities were determined using the document analysis method. According to the results, from the primary school life skills course, the participants selected 27 topics belonging to the first grade, 20 topics belonging to the second grade and 17 topics belonging to the third grade.

Table 2

Topics selected by the prospective teachers in the preparation of empathy-based activities

\begin{tabular}{|c|c|c|}
\hline Grades & Topics & $\begin{array}{l}\text { Number of } \\
\text { prospective } \\
\text { teachers (f) }\end{array}$ \\
\hline \multirow{9}{*}{ First-grade } & Let's protect plants and animals & 7 \\
\hline & Traffic rules & 5 \\
\hline & What if there were no resources & 4 \\
\hline & I need help & 4 \\
\hline & Live together & 2 \\
\hline & Safety rules & 2 \\
\hline & Wasted food & 1 \\
\hline & Rules to obey in the meal & 1 \\
\hline & Let's be gentle & 1 \\
\hline \multirow{7}{*}{ Second-grade } & I am eating healthily & 5 \\
\hline & Emergency numbers & 4 \\
\hline & Do not cut down trees & 3 \\
\hline & Let's help each other & 3 \\
\hline & Let's listen first & 2 \\
\hline & Fire & 2 \\
\hline & Earthquake & 1 \\
\hline \multirow{8}{*}{ Third-grade } & $\begin{array}{l}\text { Let's learn about traffic lights and } \\
\text { signs }\end{array}$ & 5 \\
\hline & Nature and human beings & 4 \\
\hline & A clean environment & 2 \\
\hline & Responsibility projects & 2 \\
\hline & Differences are natural & 1 \\
\hline & Savings in our home & 1 \\
\hline & Our behaviour affects all of us & 1 \\
\hline & All together hand-to-hand & 1 \\
\hline Total & & 64 \\
\hline
\end{tabular}




\section{Acta Educationis Generalis \\ Volume 9, 2019, Issue 3}

Among the first-grade topics was 'let's protect plants and animals' chosen by seven participants. This was followed by 'traffic rules' $(n=5)$, 'what if there were no resources' $(n=4)$, and 'I need help' $(n=4)$. Examples of the empathetic roles depicted by the prospective teachers about the protection of plants and animals were as follows: a child who loves and protects animals and plants, birds being fed in the park, children breaking the branches of a tree, a cat living in the park, and a garbage bin in the park.

'I am eating healthily' was the topic most addressed by the prospective teachers $(\mathrm{n}=5)$. Four participants chose the topic 'emergency numbers' and three participants each selected the topics, 'do not cut down trees' and 'let's help each other'. The empathic roles presented by the prospective teachers about eating healthily depicted a child constantly eating junk food, a child with a healthy diet, the stomach of a child who ate healthily, and the teeth of a child with an unhealthy diet.

The third-grade topic most selected by the prospective teachers was 'let's learn about traffic lights and signs' $(\mathrm{n}=5)$. This was followed by 'nature and human beings' chosen by four participants. The empathic roles related to the traffic lights and signs topic were as follows: a vehicle involved in an accident, traffic police, a person injured in an accident, ambulance officers, people trying to cross the street, and an old woman sitting in her house being disturbed by the noise of a vehicle horn outside.

The collected data showed that the prospective teachers selected topics in an increasing manner from the first to the third grade and provided various empathic roles related to these topics.

\subsection{Types of empathy chosen by the prospective teachers in the preparation of empathy-based activities}

The document analysis method was used to examine the types of empathy used by the prospective teachers when preparing empathy-based activities.

\section{Table 3}

Types of empathy chosen by the prospective teachers in preparing empathybased activities

\begin{tabular}{lc}
\hline Types of empathy & Number of prospective teachers $(f)$ \\
\hline Written empathy & 39 \\
Drawings & 15 \\
Photography & 10 \\
\hline Total & 64 \\
\hline
\end{tabular}

According to the results of this analysis (Table 3), 39 prospective teachers presented written empathy activities. In addition, the empathy activities were 


\section{Acta Educationis Generalis \\ Volume 9, 2019, Issue 3}

prepared by 15 participants using drawings, and photography was the medium chosen by 10 participants.

2.4 Feelings and thoughts of prospective teachers in the preparation of empathy-based activities

An open-ended questionnaire was used to ascertain the feelings and thoughts of the prospective teachers when preparing the empathy-based activities. Each participant presented more than one opinion about this issue (Table 4).

Table 4

The prospective teachers' reported feelings and thoughts when preparing empathy-based activities

\begin{tabular}{llc}
\hline Main themes & Subthemes & $\begin{array}{c}\text { Number of } \\
\text { prospective } \\
\text { teachers }(f)\end{array}$ \\
\hline & $\begin{array}{l}\text { Understanding the importance of } \\
\text { empathising }\end{array}$ & 18 \\
& $\begin{array}{l}\text { Making efforts to assume the } \\
\text { empathic role }\end{array}$ & 8 \\
& $\begin{array}{l}\text { Understanding the characters' } \\
\text { experience }\end{array}$ & 7 \\
Positive & Examining feelings and thoughts & 6 \\
feelings and & Feelings of happiness and peace & 6 \\
thought & Facing the future with hope & 3 \\
& Feeling that their empathy skills are & 3 \\
& improving & 2 \\
& Making associations with their own & \\
\hline & lives & 17 \\
Negative & Feelings of sadness and sorrow & 10 \\
feelings and & Feelings of a lack of empathy & 4 \\
thoughts & Feeling desperate and uncomfortable & 4 \\
& Feeling anger and annoyance & 3 \\
\hline & Feeling confused & 2 \\
\hline
\end{tabular}

The participants reported both positive and negative feelings and thoughts about the empathy-based activities. Among the positive feelings and thoughts, the most mentioned was the importance of empathising. Regarding this issue, S4 commented: "The activity I prepared was about energy sources and I tried to attract attention to energy saving. Through these activities, I understood how important it was to empathise in daily life." Similarly, S14 stated: "Empathy- 


\section{Acta Educationis Generalis \\ Volume 9, 2019, Issue 3}

based activities taught me in which situations people might need help. Now I understand how important empathising is."

It was also determined that eights teachers made efforts to assume an empathic role and seven were able to understand the experience of the characters in the texts. In relation to this, S12 provided the following explanation: "In my activity, I tried to put myself in the shoes of a child using a hearing aid and I assumed his role. Thus, I tried to imagine what he went through and developed an understanding of the difficulty of the situation he was in."

Six prospective teachers reported that they were better able to analyse their feelings and thoughts and they felt a sense of happiness and peace after implementing these activities. S1 commented: "I think we can instil the feeling of empathy in children through a daily life event. This will allow them to examine the feelings and thoughts of others around them. This makes me happier and more hopeful about the future."

Concerning negative feelings and thoughts, the most addressed were the feelings of sadness and sorrow experienced by 17 prospective teachers related to a text depicting tragic events. This was explained by S7 as follows: "I was very upset that a tree that had lived happily in the forest was burned down because of the lack of care of people. I was so angry that people were so selfish and unconcerned."

A further 10 teachers stated that they felt the lack of empathy in their daily lives. This was further elucidated by S3 as: "First of all, I thought of all the injustice in the world. We have separated people as rich-poor, black-white, and lazyhardworking. Then, we ask children to love and help each other. Yet, we first need to learn how to love each other, empathise in our daily lives. Only if we achieve this can we teach children to empathise."

The data obtained from the study revealed that the prospective teachers had both positive and negative feelings and thoughts concerning the empathy-oriented activities. The very fact that they had such feelings and thoughts was considered to be the indication that the implemented activities improved their empathy skills.

\subsection{Benefits of empathic activities for primary school students}

All the prospective teachers mentioned that they were willing to perform similar empathy-based activities in their future classrooms. When asked to explain why, the participants provided various opinions concerning the benefits of such activities for their future students, which were collected under two main themes as directly and indirectly associated with the process of empathising (Table 5). 


\section{Acta Educationis Generalis \\ Volume 9, 2019, Issue 3}

Table 5

Benefits of empathy-based activities for primary school students as reported by prospective teachers

\begin{tabular}{llc}
\hline Main themes & Subthemes & $\begin{array}{c}\text { Number of } \\
\text { prospective } \\
\text { teachers }(f)\end{array}$ \\
\hline $\begin{array}{l}\text { Directly associated } \\
\text { with the process of } \\
\text { empathising }\end{array}$ & $\begin{array}{l}\text { Putting oneself in others' shoes } \\
\text { Being sensitive to and understanding } \\
\text { people around them } \\
\text { Establishing qualified relationships with } \\
\text { the people around them }\end{array}$ & 17 \\
$\begin{array}{l}\text { Understanding the feelings and thoughts } \\
\text { of the living beings around them }\end{array}$ & 13 \\
\hline $\begin{array}{l}\text { Comprehending different academic } \\
\text { topics }\end{array}$ & 9 \\
$\begin{array}{l}\text { Recognising problems and seeking } \\
\text { associated with the } \\
\text { process of } \\
\text { empathising }\end{array}$ & $\begin{array}{l}\text { Thinking of possible outcomes before } \\
\text { performing a certain action } \\
\text { Gaining different perspectives for } \\
\text { events } \\
\text { Improving imagination } \\
\text { Being motivated and enjoying the } \\
\text { activities } \\
\text { Using empathy as a way to attract } \\
\text { others' attention }\end{array}$ & 5 \\
\hline
\end{tabular}

Concerning the direct benefits of the empathy-based activities for primary school students, 29 prospective teachers referred to empathy allowing students to put themselves in others' shoes. For example, S2 expressed his/her view about this issue as: "Through empathy-based activities, primary school students can put themselves in others' shoes, understand the feelings and thoughts of a human being or animal, and adjust their own behaviour accordingly." In addition, S41 commented, "Students can assume an empathic role in these activities, associate themselves with a character in stories and develop an understanding of the problems experienced by that character. Looking at events from the perspective of another person also allows the distancing of oneself from selfishness."

According to the prospective teachers, other potential benefits of empathy included being sensitive to, and understanding others around $(n=17)$ and being able to establish qualified relationships. Nine participants mentioned that 


\section{Acta Educationis Generalis \\ Volume 9, 2019, Issue 3}

empathy-based activities would help students to understand the feelings and thoughts of the living beings around them. In this regard, S40 provided the following explanation: "[empathy-based activities] allow us to empathise with the living beings around us, establish qualified relationships, understand their feelings and thoughts, and thus being more sensitive to the problems experienced by others."

In relation to the opinions that were indirectly associated with the process of empathising, 14 prospective teachers considered that empathy-based activities could help primary school students to comprehend various academic topics. S8 stated: "I think I can teach my future students various academic topics through empathy. For me, it is very appropriate to teach most subjects related to life skills and social studies through empathising."

Nine prospective teachers reported that empathy-based activities would help their future students to recognise problems and seek solution. A further five participants commented that empathy encouraged students to think before acting, develop different perspectives towards events, and improve their imagination. The view of S11 was: "By getting children to develop different perspectives, they can learn how to think first and act later. Empathy allows children to recognise problems and seek different solutions."

According to the results obtained from the study, the prospective teachers considered that empathy would have several directly and indirectly related positive contributions to their future primary school students. Therefore, it was concluded that the prospective teachers were willing to perform empathy-based activities with primary school students in their future classrooms.

\section{Discussion, conclusion, and recommendations}

This study aimed to determine the changes in prospective teachers' empathy levels and views on the use of empathy in the classroom after implementing the empathy-based education programme.

According to the findings obtained from the quantitative data, the empathybased education programme provided for the prospective teachers caused a significant increase in their empathy levels. Similarly, in a study by Ekinci and Aybek (2010), who applied a critical thinking programme and empathic tendency scale to prospective teachers, reported a positive correlation between critical thinking and empathic tendency at a low-level significance.

Based on this result, the authors suggested that improving critical thinking and empathy skills was important especially for teacher candidates. Furthermore, Uzunkol and Yel (2016) conducted a study to determine the effect of a value education programme based on respect and responsibility on students' selfesteem, social problem solving, and empathy. They concluded that the value education programme integrated into the life skills course had a positive effect on the empathy levels of the third-grade primary school students. 


\section{Acta Educationis Generalis \\ Volume 9, 2019, Issue 3}

According to the findings obtained from the qualitative data, the topics chosen for the preparation of empathy-based activities were mostly from the life skills subjects of the first grade of primary school, followed by second and third grades. This may be because the prospective teachers considered it appropriate to perform empathy-based activities with children from the earliest age. Furthermore, a higher number of participants chose to prepare written empathybased activities, followed by drawing and photography, which might be attributed to their belief that they could better express themselves through writing, rather than drawing or taking/showing pictures.

The findings of the current research revealed that the prospective teachers had both positive and negative feelings and thoughts concerning the implemented empathy-based activities. The very presence of these feelings and thoughts was an indication that the activities were very useful in developing the participants' empathic ability. An interesting finding was that the prospective teachers not only experienced positive feelings and thoughts when engaging in empathic activities but also internalised negative feelings, such as anger, sadness, unworthiness, and unhappiness due to the negative situations in these activities.

Another important finding of the study was that the prospective teachers believed the positive contribution of empathy to primary school students, and their views were categorised as either directly or indirectly related to empathy. The prospective teachers considered that empathic activities led students to develop more qualified relations and be more sensitive and understanding towards the people around them. Barnett and Thompson (2001) supported these findings and emphasised the important role of empathic work undertaken especially with primary school students. In a similar vein, a study conducted with the fourth- and fifth-grade primary school students showed that the students with a higher level of empathy were more helpful and behaved better towards their peers. Again, in a study by McAllister and Irvine (2002), the data obtained from the interviews with teachers promoted the importance of empathy. Empathy was found to help the teachers create a supportive classroom environment for students and encourage the students to engage in more positive interactions.

According to the prospective teachers in the current study, another potential benefit of empathy is its positive academic contribution to their future students. Feshbach and Feshbach (2009) arrived at a similar conclusion supporting this finding, noting that empathy had a direct impact on academic success and empathy facilitated learning in reading, literature and social studies.

Lastly, the prospective teachers believed that empathy helped children understand the feelings and thoughts of other living beings around them. Consistent with this finding, Feshbach and Feshbach (2009) suggested that empathy allowed children to better understand the roles and perspectives of fictional and historical characters, and children with a higher level of empathy were abler to share the feelings of the characters in texts. 


\section{Acta Educationis Generalis \\ Volume 9, 2019, Issue 3}

In conclusion, empathy is considered to be very important especially in the education of children of young age. As revealed by the review of literature, empathy skills also affect many positive elements. For this reason and considering that the available research in the literature is based either on quantitative or on qualitative data, more mixed-design studies are needed to investigate the effects of similar empathy-based education programmes integrated into life skills and social studies courses. In addition, it is as important to conduct empathy-based activities in other courses of the primary and middle school as in life skills and social studies courses. It is also suggested that empathy-based education should also be provided for teacher candidates enrolled in science teaching programmes, as well as those in social studies.

\section{References}

Barnett, M. A., \& Thompson, S. (2001). The role of perspective taking and empathy in children's machiavellianism, prosocial behaviour and motive for helping. The Journal of Genetic Psychology, 146(3), 295-305.

Creswell, J. W. (2016). Research design qualitative, quantitative, and mixed methods approaches. In S. B. Demir (Trans. Eds.), Ankara: Educating Book.

Ekinci, Ö., \& Aybek, B. (2010). Analysis of the empathy and the critical thinking disposition of the teacher candidates. Elementary Education Online, 9(2), 816-827.

Elikesik, M., \& Alım, M. (2013). The investigation of empathic skills of social sciences teachers in terms of some variables. Ataturk University Journal of the Institute of Social Sciences, 17(3), 167-180.

Feshbach, N. D., \& Feshbach, S. (2009). Empathy and education. In J. Decety, \& W. Ickes (Eds.), The social neuroscience of empathy (pp. 85-98). Cambridge, MA: The MIT Press.

Kaya, B., \& Çolakoğlu, Ö. M. (2015). Adaptation of empathy quotient (EQ) scale. Inonu University Journal of Education Faculty, 16(1), 17-30. https://doi.org/10.17679/iuefd.16127895

Kabapinar, Y. (2004). Empathy through drawings as a teaching activity used in primary school social studies courses. Marmara University Ataturk Education Faculty Journal of Educational Sciences, 20, 85-100.

Kabapinar, Y. (2005). Empathy as a teaching method that can be used in teaching life science and social studies with application and evaluation criteria. Journal of Values Education, 3(9), 119-142.

Krznaric, R. (2008). You are therefore I am: How empathy education can create social change. Oxfam GB Research Report.

Lawrence, E. J., Shaw, P., Baker, D., Baron-Cohen, S., \& David, A. S. (2004). Measuring empathy: Reliability and validity of the empathy quotient. Psychological Medicine, 34, 911-924. 


\section{Acta Educationis Generalis \\ Volume 9, 2019, Issue 3}

Mareš, J. (2017). Prosocial behavior education in children. Acta Educationis Generalis, 7(2), 7-16. https://doi.org/10.1515/atd-2017-0009

McAllister, G., \& Irvine, J. J. (2002). The role of empathy in teaching culturally diverse students a qualitative study of teachers' beliefs. Journal of Teacher Education, 53(5), 433-443.

Miles, M. B., \& Huberman, A. M. (1994). An expanded sourcebook qualitative data analysis. London: Sage Publications.

Ministry of National Education. (2018). Life studies course curriculum: 1st, 2nd and 3rd grades. Ankara: Ministry of National Education Publishing.

Patton, M. Q. (2014). Qualitative research \& evaluation methods. M. Bütün, \& S. B. Demir (Trans. Eds.), Ankara: Pegem Publishing.

Peck, N. F., Maude, S. P., \& Brotherson, M. J. (2015). Understanding preschool teachers' perspectives on empathy: A qualitative inquiry. Early Childhood Education Journal, 43(3), 169-179.

Sinclair, B. B. \& Fraser, B. J. (2002). Changing classroom environments in urban middle schools. Learning Environments Research, 5, 301-328.

Şahin, M. (2012). An investigation into the efficiency of empathy training program on preventing bullying in primary schools. Children and Youth Services Review, 34, 1325-1330.

Tamášová, V., \& Barnová, S. (2019). Coping with adversity in the lives of children in foster care. Acta Educationis Generalis, 9(1), 1-19. https://doi.org/10.2478/atd-2019-0001

Tettegah, S. (2007). Pre-service teachers' victim empathy: Cognitions, problem solving and technology. Technology, Instruction, Cognition and Learning, 5, 41-68. 